Article

\title{
Increasing Biogas Yield from Fodder by Microbial Stimulation of Propionic Acid Synthesis in Grass Silages
}

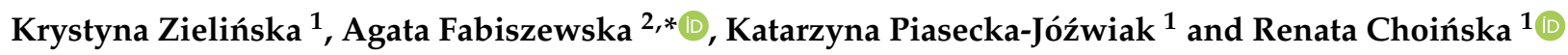 \\ 1 Department of Fermentation Technology, Prof. Wacław Dabrowski Institute of Agricultural and Food \\ Biotechnology-State Research Institute, Rakowiecka 36 Street, 02-532 Warsaw, Poland; \\ krystyna.zielinska@ibprs.pl (K.Z.); katarzyna.piasecka@ibprs.pl (K.P.-J.); renata.choinska@ibprs.pl (R.C.) \\ 2 Department of Chemistry, Institute of Food Sciences, Warsaw University of Life Sciences, \\ 159 c Nowoursynowska Street, 02-787 Warsaw, Poland \\ * Correspondence: agata_fabiszewska@sggw.edu.pl; Tel.: +48-22-59-37-621
}

check for updates

Citation: Zielińska, K.; Fabiszewska, A.; Piasecka-Jóźwiak, K.; Choińska, R Increasing Biogas Yield from Fodder by Microbial Stimulation of Propionic Acid Synthesis in Grass Silages. Energies 2021, 14, 2843. https:// doi.org/10.3390/en14102843

Academic Editor: Attilio Converti

Received: 22 April 2021

Accepted: 11 May 2021

Published: 14 May 2021

Publisher's Note: MDPI stays neutral with regard to jurisdictional claims in published maps and institutional affiliations.

Copyright: (c) 2021 by the authors. Licensee MDPI, Basel, Switzerland. This article is an open access article distributed under the terms and conditions of the Creative Commons Attribution (CC BY) license (https:// creativecommons.org/licenses/by/ $4.0 /)$.

\begin{abstract}
A new direction in the use of lactic acid bacteria inoculants is their application for renewable raw materials ensiling for biogas production. The aim of the study was to demonstrate the possibility of stimulating the synthesis of propionic acid in the process of co-fermentation of selected strains of Lactobacillus buchneri and L. diolivorans as well as L. buchneri and Pediococcus acidilactici. L. buchneri KKP 2047p and P. acidilactici KKP 2065p were characterized by the special capabilities for both synthesis and metabolism of 1,2-propanediol. L. diolivorans KKP 2057p stands out for the ability to metabolize 1,2-propanediol to propionic acid. As a result of the co-fermentation a concentration of propionic acid was obtained at least 1.5 times higher in the final stage of culture in comparison to cultivating individual species of bacteria separately. The results of in vitro experiments were applied in agricultural practice, by application of two lactic acid bacteria inoculants in ensiling of grass silage and improving its suitability for biogas production. Grass silages made with the addition of the inoculant were characterized by the content of 1,2-propanediol, 1-propanol and propionic acid ensured extension of the aerobic stability from 4 to 7 days in comparison to untreated silages. It was found that the use of both inoculants resulted in an approximately $10-30 \%$ increase in biogas yield from this raw material.
\end{abstract}

Keywords: 1,2-propanediol; biogas; grass silage; Lactobacillus; Pediococcus; propionic acid

\section{Introduction}

Biodiversity of lactic acid bacteria results not only from a great number of species, but also from a variety of strains isolated from different environments, which may differ at the genetic and phenotypic level, what influences their biochemical properties, and thus their functional characteristics [1]. The biochemical knowledge on lactic acid bacteria (LAB) metabolism can be practically applied when composing bacterial starter cultures in order to stimulate the synthesis of desirable metabolites in biotechnological processes [2-4]. An economically attractive technology to generate bioenergy is the production of biogas that is a mixture of methane and carbon dioxide as the main components. Biogas is a valuable renewable energy and also a secondary energy carrier produced from biodegradable organic materials via anaerobic digestion [5]. Because of a growing demand for renewable energy production grassland biomass can be an excellent feedstock for biogas production, but its ensiling is necessary for the efficient preservation of the energy content of a crop during the bacterial fermentation. Favorable changes in the chemical properties of silages transfer into an increase in the biogas yield from the dry matter of the organic feedstock subject to methane fermentation [6].

Raw plant biomass that can be converted into methane with high process efficiency should be characterized by high lactic and acetic acid concentrations, low concentrations 
of butyric acid and ammonia-N [7,8]. Moreover, a wide range of LAB fermentation secondary products formed during ensiling can influence specific methane yield such as 1,2-propanediol and its derivatives. These low-mass metabolites also influence significantly the oxygen stability of ensiled raw material [7]. The fundamental factor determining the methane yield from ensiled plant biomass is the selection of LAB strains composing starter cultures of bacterial preparations intended for the preservation of feed and renewable raw materials $[3,4,9]$.

A number of silage inoculants have been developed with the presence of heterofermentative Lactobacillus buchneri species and contribute to the extension of the aerobic stability of ensiled plants [9]. Biochemical changes under the influence of L. buchneri species are directed into stimulating the synthesis of acetic acid and 1,2-propanediol. Bacteria of the species L. buchneri produce 1,2-propanediol in the phosphogluconate pathway with the release of carbon dioxide [10]. The results of Quide Elferink et al. [11] showed that L. buchneri and L. parabuchneri are able to synthesize 1,2-propanediol under anaerobic conditions by converting 1 mole of lactic acid to 0.5 mole of acetic acid and 0.5 mole of 1,2-propanediol [11].

L. diolivorans isolated from maize silage and described by Kroonemann et al. [12] as a new bacterial species utilizes 1,2-propanediol as the only carbon source and metabolizes it into 1-propanol and propionic acid [12]. The presence of cobalamin is an important factor for the course and efficiency of the biochemical route, because the vitamin is a cofactor of the diol dehydratase-an enzyme involved in the metabolism of 1,2-propanediol [13-15].

Zielińska et al. [16,17] described two interesting strains isolated from ensiled maize grain: L. buchneri KKP 2047p, which was characterized with the special capabilities for both synthesis and metabolism of 1,2-propanediol and L. diolivorans KKP 2057p with the ability to metabolize 1,2-propanediol to propionic acid in the presence of cobalamin. Recently, another uncommon new strain Pediococcus acidilactici was isolated from ensiled maize grain and characterized with the ability to grow in medium on 1,2-propanediol as the only carbon source, and thus revealed the ability to metabolize it. The aim of the study was to demonstrate the possibility of stimulating the synthesis of propionic acid in the process of co-fermentation of L. buchneri KKP 2047p and L. diolivorans KKP 2057p as well as L. buchneri KKP 2047p and P. acidilactici KKP 2065p. Preliminary experiments outlined the dynamics of 1,2-propanediol metabolites in new strain of $P$. acidilactici KKP 2065p cultured solely or in co-fermentation with L. buchneri KKP 2047p. The results of in vitro experiments in flasks cultures were applied in agricultural practice to demonstrate the improvement of physicochemical properties and aerobic stability of grass silage as well as improvement of silage suitability for biogas production by application of two bacterial strains inoculant during the ensiling process.

\section{Materials and Methods}

\subsection{Bacterial Strains}

In the study following strains of lactic acid bacteria were used: L. buchneri KKP 2047p, L. diolivorans KKP 2057p and P. acidilactici KKP 2065p. Strains were obtained from the Collection of Industrial Microorganisms at the prof. Wacław Dabrowski Institute of Agricultural and Food Biotechnology-State Research Institute in Warsaw and has been stored in the atmosphere of liquid nitrogen.

Genetic identification of L. buchneri, L. diolivorans and P. acidilactici species was performed by sequencing the 16S RNA gene fragment on the basis of results indicating a $99 \%$ degree of identity with the sequences for the species in the databases (www.ncbi.nlm.nih. gov /BLAST, accessed on 1 May 2021). Experimental strains identified as L. buchneri and L. diolivorans have been subjected for strain-specific reaction using RAPD-PCR (Random Amplification of Polymorphic DNA-Polymerase Chain Reaction) with M13 primer as described Andrighetto et al. [18] (5'-GAGGGTGGCGGTTCT-3'). PCR products were separated on a $1.5 \%$ agarose gel (Sigma-Aldrich, St. Louis, MO, USA) stained with fluorescent DNA stain (GelRed, Biotium Inc., Hayward, CA, USA) $[19,20]$. The RAPD analysis of those strains 
generated different bands profiles which indicated that each strain is genetically diverse (data not shown).

\subsection{Flask Cultures Experiments}

Lactic acid bacteria were cultivated for 21 days on modified MRS broth medium at $30{ }^{\circ} \mathrm{C}$ and under aerobic conditions inoculated with $3 \% \mathrm{v} / \mathrm{v}$ 24-h culture provided in Lactobacilli MRS broth (Difco, Franklin Lakes, NJ, USA). Modified MRS media contained $8.0 \mathrm{~g} / \mathrm{L}$ $(0.11 \mathrm{M})$ of 1,2-propanediol and glucose in the concentration of 2.5, 5.0 and $10.0 \mathrm{~g} / \mathrm{L}$ when Lactobacillus co-fermentations were provided. Modified MRS media contained $6.0 \mathrm{~g} / \mathrm{L}$ $(0.09 \mathrm{M})$ or $8.0 \mathrm{~g} / \mathrm{L}(0.11 \mathrm{M})$ of 1,2-propanediol and alternatively glucose in the concentration of $5.0 \mathrm{~g} / \mathrm{L}$, when Pediococcus species was cultured singly or along with L. buchneri. Vitamin B12 $(100 \mu \mathrm{g} / \mathrm{L})$ was added in each trial. In order to determine the dynamics of synthesis of the studied metabolites, supernatant samples were taken for analysis after 3, 7, 14 and 21 days. Bacterial biomass was centrifuged using a Jouan CR 3i centrifuge (Jouan S.A., Saint Herblain, France) (10,000 rpm, $\left.10 \mathrm{~min}, 15^{\circ} \mathrm{C}\right)$.

\subsection{Grass Silage Production}

Silage experiments were carried out under production conditions at the experimental station of the Institute of Technology and Life Sciences in Poland. Bacterial inoculants were prepared as described previously [21]. Biomass of bacteria was grown in biofermentors, at a temperature of $30{ }^{\circ} \mathrm{C}$, with $\mathrm{pH}$ adjusted with the use of ammonia water to the value of 5.7 for $24 \mathrm{~h}$. After centrifugation the biomass was mixed with carriers and biostimulants and freeze-dried. The finished preparation contained a bacterial count of $2 \times 10^{10} \mathrm{CFU} / \mathrm{g}$. Experimental silages from grasses were sprayed with the inoculant Biogas A which consisted of L. buchneri KKP 2047p and L. diolivorans KKP 2057p (50\%: 50\%) strains or inoculant Biogas B which consisted of L. buchneri KKP 2047p and P. acidilactici KKP 2065p (50\%: $50 \%$ ). Control silages were prepared without the bacterial inoculant. All silages were made from plants withered after cutting with a dry matter content of approximately $40-50 \%$. The preparation, at a dose of $2 \times 10^{5} \mathrm{CFU} / \mathrm{g}$ of fresh plants was given after dissolving in water, in form of spraying using an applicator, before the plants were rolled up and bales were formed with an average weight of about 500-900 kg in stationary wrapping machine Metal-Racch Z-237. After 60 days of ensiling the probes were taken for analyses and $\mathrm{pH}$ value, lactic, acetic, 3-hydroxybutyric and propionic acids, 1-propanol and 1,2propanediol content were determined. Control and experimental silages were subjected for biogas production.

\subsection{Biogas Yield and Biogas Content Determination}

Biogas yield was determined by methane fermentation method according to analytical procedure of Institute of Technology and Life Sciences in Poland. Biogas composition was determined by GA 2000 Geotechnical Instruments and Multi Gas gauge (United Kingdom). Determination of biogas yield from dry organic matter of agricultural raw material by five-week laboratory methane fermentation of samples with saturation of $10 \%$ organic substrates was performed according to German standard method DIN 38414-8 [22]. Unit of biogas yield-NI / kg organic dry matter (odm) is a standardized net liter of biogas obtained from the $1 \mathrm{~kg}$ of organic dry material of a given sample and refers to the stated dry matter content and organic dry matter content.

\subsection{Analytical Methods}

The extract of macerated silage was prepared with distilled water as described previously [21]. An adjusted dry matter content was determined according to ISO standard (PN-ISO 6496: 2002) and pH using the potentiometric method. Determination of L- and Dlactic acid content, acetic and 3-hydroxybutyric acid contents were conducted by enzymatic methods according to the manufacturer's protocols (Boehringer, Mannheim, Germany). Propionic acid, 1-propanol and 1,2-propanediol were determined by gas chromatography 
according to Zielińska et al. [21]. Lactobacilli cells were enumerated by pour plating of Lactobacilli MRS agar medium according to ISO standard (PN-ISO 15214:2002). Aerobic stability test was performed according to Honig [23]. Determination of organic dry matter of silage was provided during combustion at $550{ }^{\circ} \mathrm{C}$ in Carbolite RWF 1200 muffle furnace. Biogas yield from ensiled renewable raw materials was performed by methane fermentation method, analysis of biogas composition was done using the GA 2000 Geotechnical Instruments and Multi Gas meter, Monitor 1312 Innova.

\subsection{Statistical Analyses}

The results were analyzed using STATISTICA 13.1 software (TIBCO Software Inc., Palo Alto, CA, USA). Standard deviations were calculated. To verify the statistical hypothesis about the normality of the distribution of experimental data, the Shapiro-Wilk test was used, and the hypothesis about the homogeneity of variance was verified using the Levene test and the Brown-Forsythe test. The ANOVA (analysis of variance) was used to assess the significance of differences. Tukey post-hoc test was applied to organize data in homogenous groups [24]. The significance level $\alpha=0.05$ was chosen. Experiments were provided at least in triplicates.

\section{Results}

3.1. Stimulation of Propionic Acid Synthesis in the Co-Fermentation of L. buchneri KKP 2047p and L. diolivorans KKP 2057p

The aim of the preliminary flask culture experiment was to demonstrate the possibility of stimulating the synthesis of propionic acid in the process of co-fermentation of L. buchneri KKP 2047p and L. diolivorans KKP 2057p. There were provided three independent cofermentations in modified MRS media, in which 1,2-propanediol was applied at a constant concentration $(8.0 \mathrm{~g} / \mathrm{L})$ and variables amounts of glucose, respectively; $2.5 ; 5.0$, and $10.0 \mathrm{~g} / \mathrm{L}$ were used. The research has tended to focus on the importance of the second carbon source (glucose) presence in medium in the context of maximizing the biotransformation of 1,2propanediol into carboxylic acid. The characteristics of the biochemical features of $L$. buchneri KKP 2047p and L. diolivorans KKP 2057p strains are presented in Table 1 and related to their ability to synthesize and/or metabolize 1,2-propanediol to propionic acid. Table S1 and Figure 1 report the dynamics of synthesis and production of carboxylic acids and their derivatives during 21 days of culture.

Table 1. Ability of strains species L. buchneri. L. diolivorans and P. acidilactici to synthesize and/or metabolize 1,2-propanediol.

\begin{tabular}{|c|c|c|c|c|}
\hline \multirow[b]{2}{*}{ Lactobacillus Strain } & \multirow[b]{2}{*}{ Source of Species/Strain Isolation } & \multicolumn{2}{|c|}{ Specific Features } & \multirow[b]{2}{*}{ Reference } \\
\hline & & $\begin{array}{c}\text { 1,2-propanediol * } \\
\text { Content, Synthesized } \\
\text { from Glucose, } \mathrm{mg} / 100 \mathrm{~mL}\end{array}$ & $\begin{array}{c}\text { Propionic Acid } \\
\text { Content, mg/100 mL }\end{array}$ & \\
\hline L. buchneri KKP 2047p & maize silage & $400.00 *$ & $174.9^{1}$ & 17,18 \\
\hline L. buchneri KKP 907p & meadow sward & $120.00 *$ & no detected & 24,37 \\
\hline L. diolivorans LMG 19667 & maize silage & no & $125.8^{2}$ & 13 \\
\hline L. diolivorans KKP 2057p & maize silage & no & $125.4^{1}$ & 18 \\
\hline P. acidilactici KKP 2065p & buckwheat grain & no & $248.20^{3}$ & - \\
\hline
\end{tabular}

${ }^{*}$ bacteria grown in MRS medium, ${ }^{1}$ bacteria grown in modified MRS medium (1,2-propanediol— $8.0 \mathrm{~g} / \mathrm{L} ;$ glucose $\left.10.0 \mathrm{~g} / \mathrm{L}\right),{ }^{2}$ bacteria grown in modified MRS medium (1,2-propanediol-2.9 g/L), 21 days, $30^{\circ} \mathrm{C}^{3}$ bacteria grown in modified MRS medium $(1,2$-propanediol-8.0 g/L; glucose $5.0 \mathrm{~g} / \mathrm{L}$.

The general trend was observed for all variants of the experiment (Figure 1). The content of acetic acid and the intermediate metabolites of its conversion-propionic acid and 1-propanol, increased until the 14th day of culture. After then the concentration of 1-propanol decreased but the content of propionic acid increased to the end, reaching on $21 \mathrm{st}$ day the level of $223.0 \mathrm{mg} / 100 \mathrm{~mL}$ in medium containing $10.0 \mathrm{~g} / \mathrm{L}$ glucose. The degree of 1,2-propanediol utilization reached $90.0 \%$. When glucose content was lowered twice to $5.0 \mathrm{~g} / \mathrm{L}$, the propionic acid content reached on the 21st day of culture a higher level by $20 \%$ than that in medium with $10.0 \mathrm{~g} / \mathrm{L}$ of glucose i.e., $270.09 \mathrm{mg} / 100 \mathrm{~mL}$. The utilization rate 
of 1,2-propanediol was $93.0 \%$. Lowering the glucose concentration in the medium to the value of $5.0 \mathrm{~g} / \mathrm{L}$ did not negatively affect the development of bacterial growth (Figure 1). On the 3rd day of culture, the number of bacterial cells grown in both media reached $4.0 \times 10^{9} \mathrm{CFU} / \mathrm{mL}$ (Table S1).

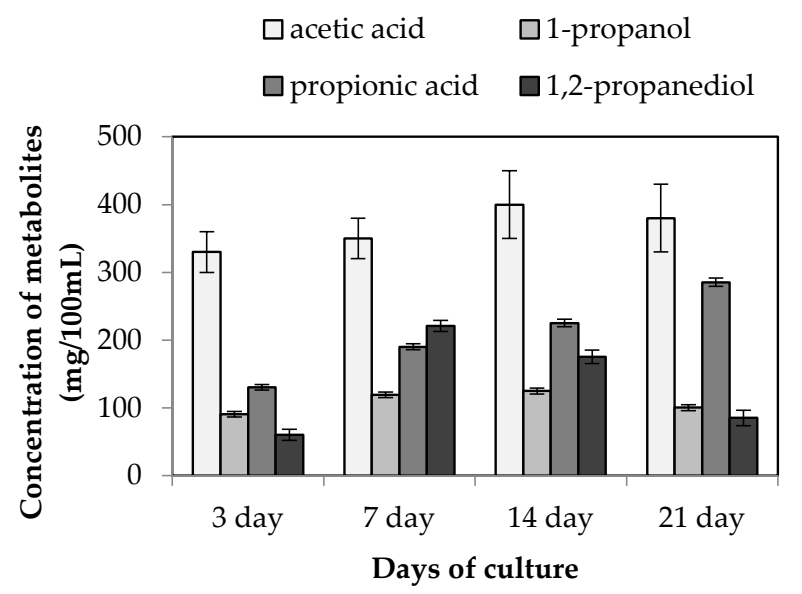

(a)

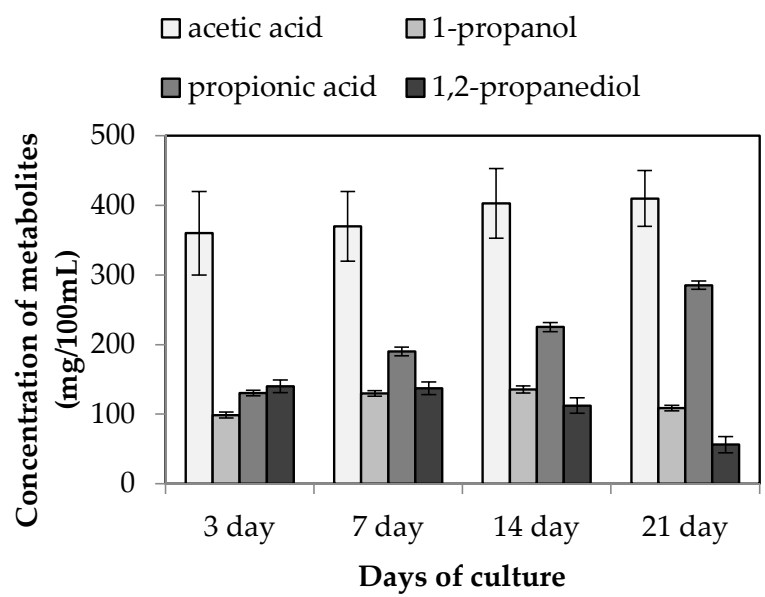

(b)

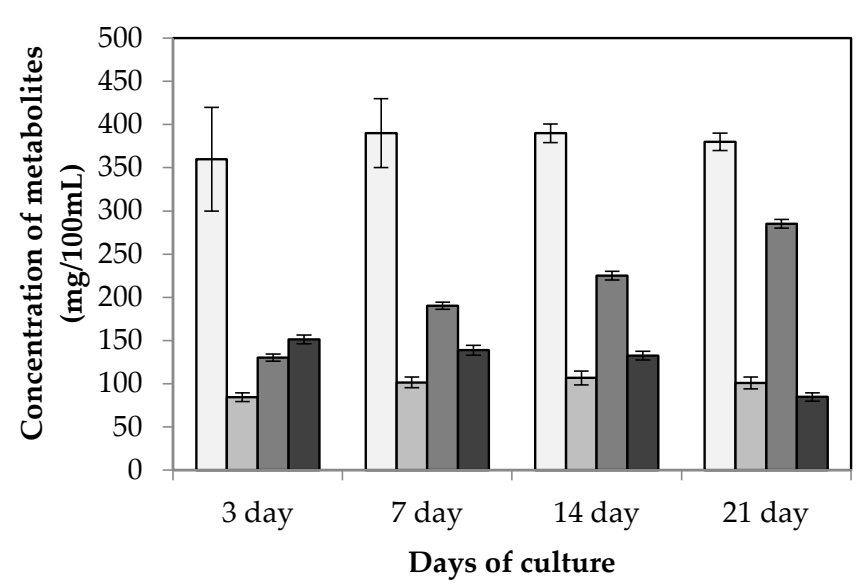

(c)

Figure 1. Metabolite profile of supernatant resulting from co-fermentation of strains L. buchneri KKP 2047p and L. diolivorans KKP 2057p in medium containing $8.0 \mathrm{~g} / \mathrm{L}$ 1,2-propanediol and glucose as a carbon sources in concentration: (a) $2.5 \mathrm{~g} / \mathrm{L}$; (b) $5.0 \mathrm{~g} / \mathrm{L}$; (c) $10.0 \mathrm{~g} / \mathrm{L}$. There was showed a standard deviation for each measurement.

In the experimental variant with a $2.5 \mathrm{~g} / \mathrm{L}$ glucose content in medium the content of propionic acid in the final day of research was $285.20 \mathrm{mg} / 100 \mathrm{~mL}$, it increased only by $15 \mathrm{mg} / 100 \mathrm{~mL}$ in relation to the results obtained during the cultivation of lactobacilli in medium with $5.0 \mathrm{~g} / \mathrm{L}$ of glucose. The growth of bacterial cells on the 3rd day of culture was three times less intensive, and the degree of the use of 1,2-propanediol decreased to $85.0 \%$ (Figure 1, Table S1).

It was found that the addition of glucose at the level of at least $5.0 \mathrm{~g} / \mathrm{L}$ turned out to be essential for the optimal growth of 2-strain bacterial starter culture consisted of L. buchneri KKP 2047p and L. diolivorans KKP 2057p. Therefore, almost all loadings of 1,2-propanediol were used for lactobacilli growth and biotransformation to expected metabolites. Further reduction of glucose to the level of $2.5 \mathrm{~g} / \mathrm{L}$ inhibited the growth and metabolism of bacterial cells. Moreover, it has been shown that the process of propionic acid synthesis depends to a large extent on the carbon source used in the culture medium and as a consequence the 
interaction of the L. buchneri KKP 2047p and L. diolivorans KKP 2057p. The complementary ability of these bacteria to synthesize and to metabolize 1,2-propanediol to propionic acid was proved phenotypically and investigated during ensiling of grass in the next step of the study.

\subsection{Stimulation of Propionic Acid Synthesis in L. buchneri KKP 2047p and P. acidilactici KKP $2065 p$ Co-culture}

The newly isolated P. acidilactici KKP 2065p with the unexpected ability to synthesize propionic acid was a subject of further investigations aimed to provide evidence of its usefulness in composing LAB starter cultures. Firstly, Pediococcus strain was cultured solely in media with 1,2-propanediol or glucose as carbon sources. Table S2 and Figure 2 illustrates changes in the content of metabolites measured after 3, 7, 14 and 21 days. What can be observed, independently from the level of 1,2-propanediol used (6.0 or $8.0 \mathrm{~g} / \mathrm{L})$ the content of 1-propanol and propionic acid increased, while acetic acid and 1,2-propanediol concentration decreased. On 21st day of the experiment, the utilization rate of 1,2-propanediol reached $98 \%$ for all variants. The highest change in the content of propionic acid was observed between 3rd and 7th day when cultures reached the stationary growth phase (from 47.17 to $119.13 \mathrm{mg} / 100 \mathrm{~mL}$ in the medium containing $6.0 \mathrm{~g} / \mathrm{L}$ 1,2 propanediol without glucose, from 87.05 to $150.40 \mathrm{mg} / 100 \mathrm{~mL}$ in medium containing $6.0 \mathrm{~g} / \mathrm{L} \mathrm{1,2} \mathrm{propanediol} \mathrm{and} 5.0 \mathrm{~g} / \mathrm{L}$ glucose, and from 112.10 to $180.40 \mathrm{mg} / 100 \mathrm{~mL}$ in the medium containing $8.0 \mathrm{~g} / \mathrm{L} \mathrm{1,2}$ propanediol and $5.0 \mathrm{~g} / \mathrm{L}$ glucose).

The third medium was characterized by an increased content of 1,2-propanediol to $8.0 \mathrm{~g} / \mathrm{L}$ with the addition of glucose in the same dose as in the second medium $(5.0 \mathrm{~g} / \mathrm{L})$. Under these conditions the strain of P. acidilactici was grown separately, as well as in the combined co-fermentation with L. buchneri KKP 2047p to demonstrate the synergy of their action towards stimulating the synthesis of propionic acid from 1,2-propanediol. The use of glucose in the amount of $5.0 \mathrm{~g} / \mathrm{L}$ provided a good start for the growth of the bacterial inoculum (Figure 2). On the third day of cultivation, their number in both experiments was $3 \times 10^{9} \mathrm{CFU} / \mathrm{mL}$ (Table S2). During the culture with P. acidilactici KKP 2065p single strain, the level of propionic acid on the 21st day reached the value of $248.2 \mathrm{mg} / 100 \mathrm{~mL}$ (Figure 2).

The results of the co-fermentation revealed the dynamic growth of bacteria resulting in an increase of the acetic acid content approximately 1.5 times compared to previous experimental results $(0.34 \mathrm{mg} / 100 \mathrm{~mL}$ in $3 \mathrm{rd}$ day in comparison to 0.20 in second medium when $P$. acidilactici KKP 2065p was grown solely). On the third day of the combination cultivation, the content of propionic acid reached the value of $162.10 \mathrm{mg} / 100 \mathrm{~mL}$ and at the end of the culture, its content increased to $352.00 \mathrm{mg} / 100 \mathrm{~mL}$, with the 1,2-propanediol utilization rate accounting for $99.9 \%$. In the case of co-fermentation of the synergistically acting strains of L. buchneri KKP 2047p and P. acidilactici KKP 2065p, a higher propionic acid content was obtained in the same medium by $30 \%$ compared to the cultivation of a single strain of the genus $P$. acidilactici (Figure 2).

\subsection{Improvement of Aerobic Stability of Grass Silage and Biogas Yield under the Influence of the Lactic Acid Bacteria Inoculants}

Promising results of the in vitro studies were next used in the farm practice. The action of the inoculant Biogas A containing L. buchneri KKP 2047p and L. diolivorans KKP 2057p strains in a 1:1 ratio and inoculant Biogas B containing L. buchneri KKP 2047p and P. acidilactici KKP 2065p in a 1:1 ratio was observed at a production scale. In order to assess the effectiveness of ensiling the chemical composition, oxygen stability and biogas yield of experimental silages, treated with the bacterial inoculants and untreated control silages were compared.

The oxygen stability test was carried out for 11 days after opening the silo by temperature analysis. Experimental silages with the addition of Biogas A inoculant were characterized by extended aerobic stability up to 7 days, while control silages without the addition of the preparation were stable for only 4 days (Figure 3). The similar observations were made for the second bacterial starter culture Biogas B (data not shown). 


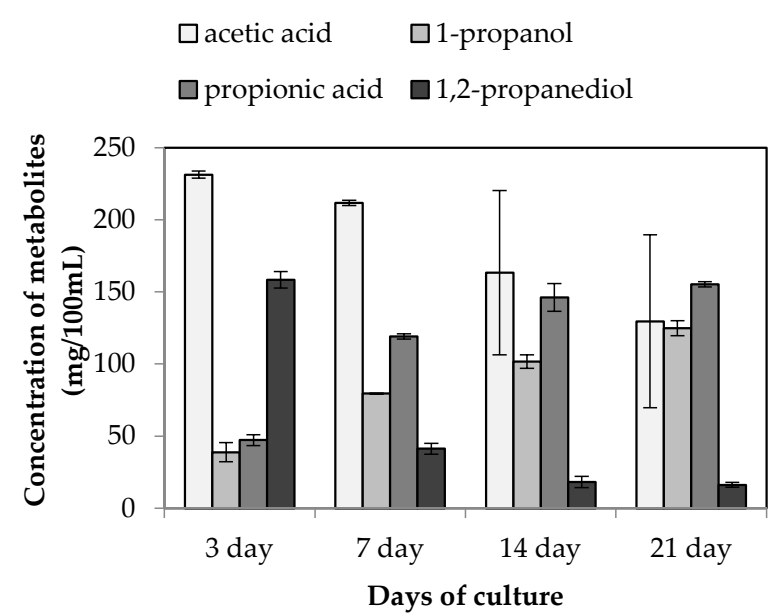

(a)

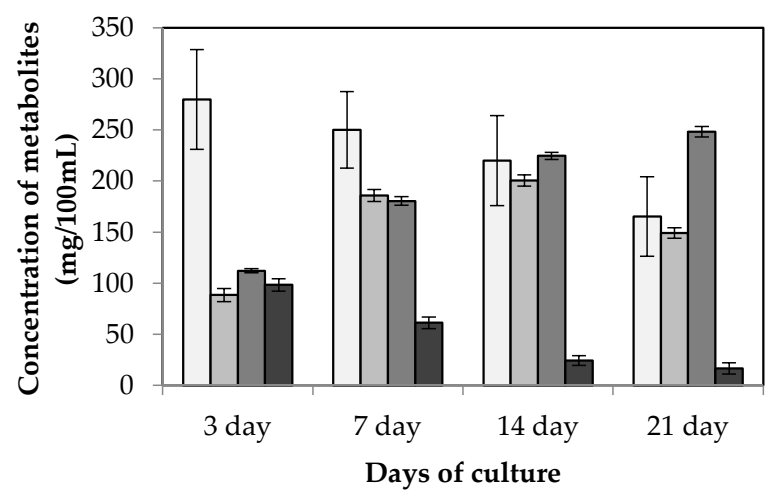

(c)

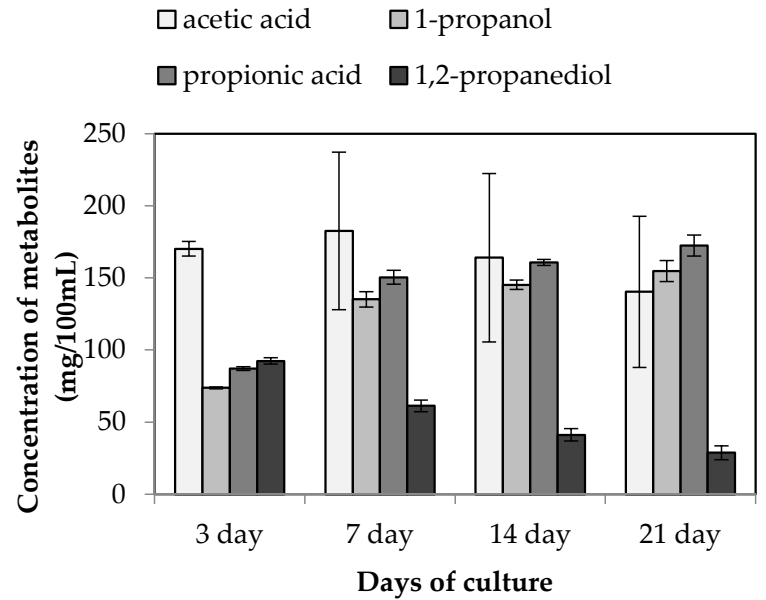

(b)

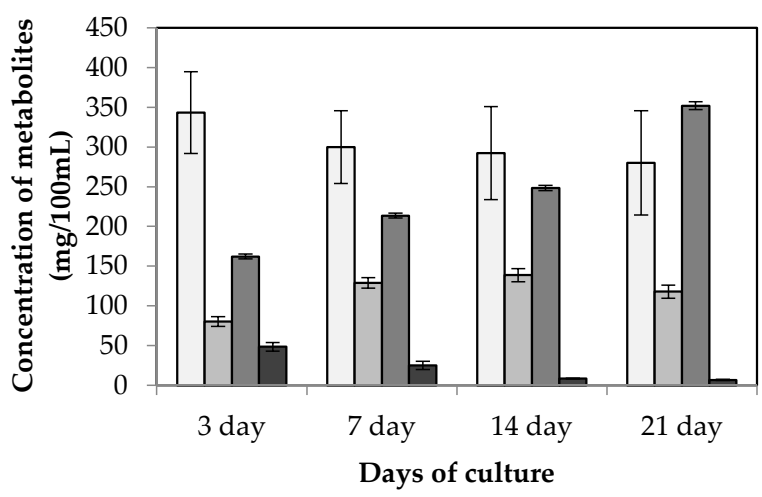

(d)

Figure 2. Metabolite profile of supernatant resulting from P. acidilactici KKP 2065p (a-c) culture and co-fermentation of strains L. buchneri KKP 2047p and P. acidilactici KKP 2065p (d) in medium containing glucose and/or 1,2-propanediol as a carbon sources (a)-medium containing $6.0 \mathrm{~g} / \mathrm{L}$ 1,2-propanediol; (b) medium containing $6.0 \mathrm{~g} / \mathrm{L}$ 1,2-propanediol and $5.0 \mathrm{~g} / \mathrm{L}$ glucose; (c,d) medium containing $8.0 \mathrm{~g} / \mathrm{L}$ 1,2-propanediol and $5.0 \mathrm{~g} / \mathrm{L}$ glucose. There was showed a standard deviation for each measurement.

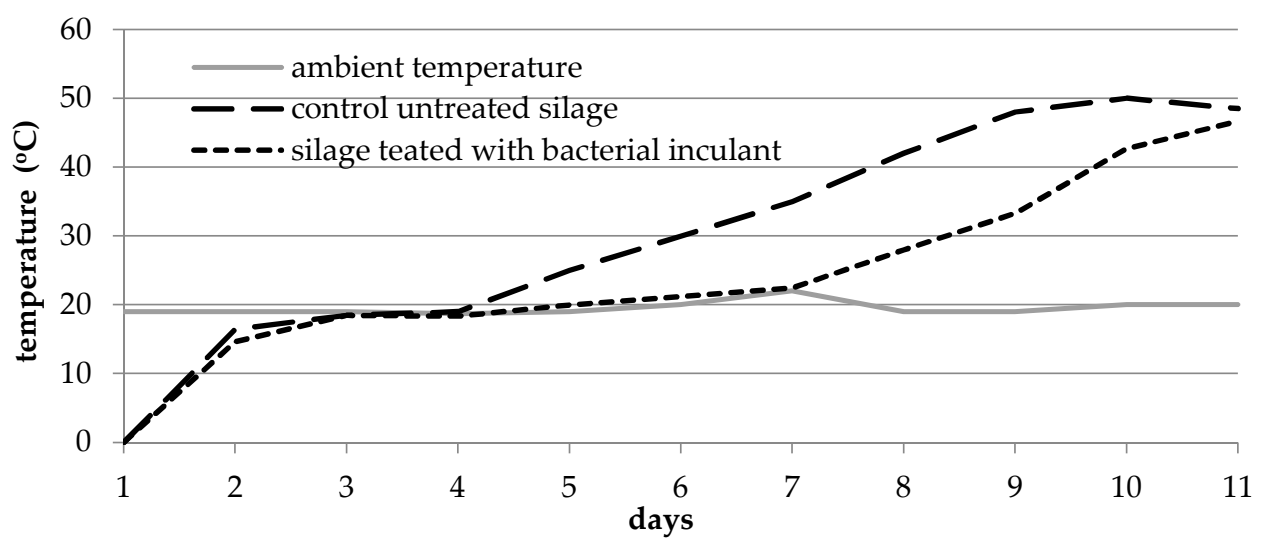

Figure 3. The effect of inoculant Biogas A consisted of L. buchneri KKP 2047p and L. diolivorans KKP 2057p on the aerobic stability test of grass silages. 
The high content of acetic acid, 1,2-propanediol and propionic acid ensures silage an extension of aerobic stability $[6,25]$. Under the influence of the bacterial preparations Biogas A and B, the experimental silages were characterized by high quality, lack of butyric acid, higher content by $25 \%$ lactic acid and about two times acetic acid and more than ten times higher content of propionic acid in relation to the concentration of those metabolites in control silage (116.4 mg/100 $\mathrm{g}$ and 138.32 when Biogas A and B inoculants were used respectively) (Table 2). In addition, 1,2-propanediol and 1-propanol were found in silages treated with Biogas A reaching 97.8 and $90.6 \mathrm{mg} / 100 \mathrm{~g}$ and 100.8 and $90.4 \mathrm{mg} / 100 \mathrm{~g}$ in Biogas B inoculated silages.

Table 2. The content of organic acids, 1,2-propanediol and 1-propanol in grass silages, prepared with and without the addition of the bacterial inoculant Biogas A consisted of L. buchneri KKP 2047p and L. diolivorans KKP 2057p or bacterial inoculant Biogas B consisted of L. buchneri KKP 2047p and P. acidilactici KKP 2065p. There was showed a standard deviation for each measurement (after the symbol " \pm "), n.d.-not detected.

\begin{tabular}{|c|c|c|c|c|c|c|c|}
\hline \multirow{2}{*}{ Silage } & \multirow{2}{*}{$\mathrm{pH}$} & \multicolumn{3}{|c|}{$\begin{array}{l}\text { Volatile Carboxylic Acids Content, } \\
\text { g/100 g of Fresh Mass Silage }\end{array}$} & \multicolumn{3}{|c|}{$\begin{array}{c}\text { Metabolite Content, } \\
\text { mg/100 g of Fresh Mass Silage }\end{array}$} \\
\hline & & Lactic & Acetic & $\begin{array}{l}\text { 3-Hydroxy } \\
\text { Butyric }\end{array}$ & 1,2-Propanediol & 1-Propanol & Propionic Acid \\
\hline Untreated (control A) & $5.10 \pm 0.1$ & $1.18^{\mathrm{a}} \pm 0.2$ & $0.22^{\mathrm{a}} \pm 0.1$ & $0.09^{\mathrm{a}} \pm 0.15$ & n.d. ${ }^{a}$ & n.d. ${ }^{a}$ & $10.8^{\mathrm{a}} \pm 3.4$ \\
\hline $\begin{array}{c}\text { Treated with bacterial inoculant } \\
\text { Biogas A }\end{array}$ & $4.48 \pm 0.1$ & $1.48^{\mathrm{a}} \pm 0.3$ & $0.45^{\mathrm{ab}} \pm 0.15$ & n.d. ${ }^{b}$ & $97.8^{\mathrm{b}} \pm 11.3$ & $90.6^{\mathrm{b}} \pm 11.4$ & $116.4^{\mathrm{b}} \pm 6.8$ \\
\hline Untreated (control B) & $4.55 \pm 0.1$ & $1.25^{\mathrm{a}} \pm 0.2$ & $0.27^{\mathrm{a}} \pm 0.1$ & $0.18^{\mathrm{a}} \pm 0.15$ & n.d. ${ }^{a}$ & n.d. ${ }^{\text {a }}$ & $8.2^{\mathrm{a}} \pm 3.4$ \\
\hline $\begin{array}{l}\text { Treated with bacterial inoculant } \\
\text { Biogas B }\end{array}$ & $4.53 \pm 0.1$ & $1.40^{\mathrm{a}} \pm 0.3$ & $0.67^{\mathrm{b}} \pm 0.15$ & n.d. ${ }^{b}$ & $100.8^{\mathrm{b}} \pm 9.3$ & $90.4^{\mathrm{b}} \pm 9.4$ & $138.32^{\mathrm{c}} \pm 6.5$ \\
\hline
\end{tabular}

a b, c-homogeneous groups designated on the basis of Tukey's test.

Biogas yields from untreated and treated silages were compared by means of fiveweek laboratory methane fermentation in order to evaluate the usefulness of bacterial inoculants for biogas purposes. The substrate loading of the fermenting mixture was $10 \%$ in these experiments. The results for biogas and methane yield are presented in Table 3. Compared to the biogas yield obtained from control silage, the methane fermentation of experimental silage resulted in biogas yield higher by 160.1 and by $45.1 \mathrm{NI} / \mathrm{kg}$ organic dry matter, additionally with a higher methane content by 8.5 and $6.7 \%$ in respect to Biogas A and B inoculants (Table 3).

Table 3. Biogas yield and biogas purity produced from grass silage: untreated (control) and treated with the bacterial inoculant Biogas A consisted of L. buchneri KKP 2047p and L. diolivorans KKP 2057p or bacterial inoculant Biogas B consisted of L. buchneri KKP 2047p and P. acidilactici KKP 2065p. There was showed a standard deviation for each measurement (after the symbol “ \pm ").

\begin{tabular}{|c|c|c|c|c|}
\hline Silage & Dry Matter, \% & $\begin{array}{l}\text { Loading the Fermentation } \\
\text { Mixture with Organic Dry } \\
\text { Matter odm } * \%\end{array}$ & $\begin{array}{l}\text { Biogas Yield } \\
\text { NI/kg odm * }\end{array}$ & Methane in Biogas, $\%$ \\
\hline Untreated (control A) & $45.0 \pm 0.9$ & $70.4 \pm 2.0$ & $367.3 \pm 18.7$ & $58.4 \pm 1.4$ \\
\hline Treated with bacterial inoculant Biogas A & $44.1 \pm 0.9$ & $69.8 \pm 2.1$ & $527.4 \pm 25.5$ & $66.9 \pm 2.1$ \\
\hline Untreated (control B) & $50.8 \pm 3.6$ & $66.4 \pm 2.1$ & $461.9 \pm 23.1$ & $61.9 \pm 2.2$ \\
\hline Treated with bacterial inoculant Biogas B & $41.5 \pm 0.9$ & $66.6 \pm 2.1$ & $507.3 \pm 23.5$ & $68.6 \pm 1.5$ \\
\hline
\end{tabular}

The use of the bacterial inoculants for grass ensiling positively influenced the biogas potential of silages. Experimental grass silages with the addition of the preparation used as a substrate for biogas production showed accelerated and anticipating dynamics of the methane fermentation process in comparison to the control silage, without its addition. The effect was more visible to the bacterial starter culture consisted of two Lactobacillus strains, but despite the closer levels of biogas yields obtained from meadow grass silages treated with Pediococcus cells, the usefulness of Biogas B inoculant was still promising. 


\section{Discussion}

Based on the results described by Zielińska et al. [16] it was evaluated that in the case of L. buchneri KKP 2047p and L. diolivorans KKP 2057p being cultured for 21 days separately, under comparable conditions to the study presented in this article, different propionic acid concentrations were obtained. For the culture of L. buchneri KKP 2047p, the final content of propionic acid was $174.9 \mathrm{mg} / 100 \mathrm{~mL}$. L. diolivorans KKP 2057p grown in modified MRS medium with 1,2-propanediol $(0.8 \mathrm{~g} / 100 \mathrm{~mL})$ was characterized by the ability to synthesize propionic acid in concentration of $122.8 \mathrm{mg} / 100 \mathrm{~mL}$ (Table 1). Kroonemann et al. [12] obtained a similar final level of propionic acid $125.8 \mathrm{mg} / 100 \mathrm{~mL}$, after 21 days of L. diolivorans LMG 19667 strain culture in medium containing 1,2-propanediol as the only carbon source (Table 1).

The results of model studies presented by the authors highlighted the synergistic effect of bacterial strains of the studied L. buchneri and L. diolivorans species what was not reported in the literature before. The finding points to complementary ability of the species to synthesize and/or metabolize 1,2-propanediol to propionic acid. As a consequence of the co-fermentation of these species, under comparable bacterial culture conditions, at least 1.5 times more propionic acid was identified in culture supernatant than in the case of individual culture of bacterial species. Further molecular studies should be provided in order to estimate the efficiency of conversion of 1,2-propanediol synthesized by L. buchneri to propionic acid synthesized by L. diolivorans.

In addition, the results have further strengthened our confidence that the level of complementary carbon source-glucose, which is a starter substrate for proliferating of lactic acid bacteria cells, has a significant impact on the synthesis of propionic acid from 1,2propanediol. In the medium with a glucose content of $5.0 \mathrm{~g} / \mathrm{L}$, the level of propionic acid after 21 days of co-fermentation was $270.09 \mathrm{mg} / 100 \mathrm{~mL}$, and after further reduction of the glucose content to $2.5 \mathrm{~g} / \mathrm{L}$, the final level of propionic acid reached $285.20 \mathrm{mg} / 100 \mathrm{~mL}$. With this culture the concentration of glucose affected bacterial growth and caused a decrease in the use of the second substrate-1,2-propanediol from 93 to $85 \%$ (Figure 1). It was found that supplementary glucose addition to the culture medium (in the amount of $5.0 \mathrm{~g} / \mathrm{L}$ ), in which the main carbon source was 1,2-propanediol, turned out to be necessary for development of bacterial inoculum and thus for metabolizing 1,2-propanediol to propionic acid by bacterial cells. Depending on the tested bacterial strain, under the same culture conditions and the availability of the basic carbon source-1,2-propanediol, a different level of the final product of its metabolism, i.e., propionic acid, could have been obtained. The same phenomenon was observed in the case of fermentation of P. acidilactici KKP 2065p. The content of propionic acid in the supernatant was much higher when glucose was a medium ingredient. Unfortunately, there are no other similar studies to compare or confront our own results.

In the current attempt, there was revealed that the newly isolated and characterized strain of P. acidilactici KKP 2065p was more effective in the process of 1,2-propanediol metabolism than the known and described strains of the species L. diolivorans, as evidenced by the data presented in Table 1 and Figure 2. This encouraged to use P. acidilactici strain in starter culture in ensiling process with the combination of other widely used and described in such studies-L. buchneri. Effects of two inoculant Biogas A and Biogas B were set together in order to compare the effect at farm conditions to prepare silages with high potential for biogas production. It is probably first attempt to apply P. acidilactici in cofermentation experiments with L. buchneri species and one of a few using starter culture containing L. diolivorans and L. buchneri species.

Our results share a number of similarities claimed by other authors, who describe improvement of aerobic stability of maize silage under the influence of bacteria of the $L$. buchneri species, as well as L. buchneri followed by the addition of commonly used lactic acid bacteria e.g., L. plantarum $[17,26,27]$. Moreover, Nishino et al. [2] found that when $L$. buchneri inoculants were used to ensilage maize, a significant improvement in the oxygen stability was observed due to the accumulation of 1,2-propanediol in the ensiled plant 
material. The positive effect of propionic acid production synthesized as a consequence of 1,2-propanediol accumulation in L. buchneri and $L$ diolivorans co-fermentation of sourdough was also described by Zhang et al. [28]. Selwet showed that maize silages inoculated with Lactobacillus strains revealed better aerobic stability than control samples due to the higher acetic and propionic acid concentrations. Silages inoculated with starter culture consisted of L. buchneri ATCC 4005, L. diolivorans LGM 19667 and L. reuteri ATCC 23272 contained $1.4 \mathrm{~g} / 100 \mathrm{~g} \mathrm{dm}$. No1,2-propanediol and 1-propanol were found in the control samples [29]. The same observations were made in our research.

Many studies have focused on improved silage quality e.g., increased silage digestibility, dry matter intake and prevention from spoilage microorganisms followed by rumen fermentation parameters [30]. Interestingly some bacterial inoculants are intentionally added prior decreasing methane production in rumen. Khota et al. [31] confirmed that L. casei TH14 could improve sorghum silage fermentation, inhibit protein degradation and decrease methane fermentation during in vitro studies. At the same time, the scientific literature lacks data on bacterial inoculants impact on biogas yield from silages. Sparse studies are in agreement with our results. McEniry et al. [8] claimed that grass silage fermentation characteristics appear to have relatively little effect on specific methane yield. However, the relatively high concentrations of fermentation products such as butyric acid in the heterofermentative LAB treatments by inoculant Pioneer 11A44 containing L. buchneri resulted in a numerically higher specific methane yield.

What can be also underlined is the fact that the common energy crops are maize or sorghum. Meanwhile the methane content achieved in grass silages in this study was more or of the same amount than other authors' results e.g., with one ton of corn silage with a content of $30 \%$ to $40 \%$ of the dry matter, biogas with a content of $50-55 \%$ methane could be obtained. With 1 ton of sorghum silage, it produced biogas with $54 \%$ methane content. The highest cumulative values of biogas production were obtained for Elvira beet, the methane content was $64 \%$ [32]. In our study the average methane content in grass silages was $66.9 \%$ and $68.6 \%$ for Biogas A and Biogas B inoculants, respectively.

\section{Conclusions}

Model experiments on co-fermentation of bacterial strains from the species: L. buchneri and L. diolivorans or P. acidilactici indicated the possibility of controlling and stimulating the synthesis of acetic acid, its conversion to 1,2-propanediol and metabolizing this compound to propionic acid. The utilization of subsequent substrates during the culture of the studied bacteria (1,2-propanediol, glucose), followed by the synthesis of 1-propanol and propionic acid, allowed their transformation in the growth environment. As a result of the cofermentation a 1.5 times higher concentration of propionic acid was obtained at least in the final stage of culture when compared with individual species of bacteria grown separately.

Lactic acid and volatile organic acids such as acetic and propionic acids are suitable methane fermentation substrates, not necessary often appreciated in order of possessing high-yield biogas. Ensiled green biomass can be rich in those volatile short-chain fatty acid and though it can be considered as a good substrate for agriculture biogas plants. In the paper we presented a method of boosting microbial processes in grass silages in order to increase especially propionic acid content and thus increasing the biogas yield in comparison to the non-inoculated fodder.

The successful transfer of microbial inoculants from the laboratory to the field remains a challenge. This is primarily due to the presence of many crop species and crop varieties, variable environmental conditions between fields, and the exponential increase in the number of microbial isolates. The limitations of collecting data during in vivo experiments on microbial culture reconstruction experiments and model organisms for understanding plant-microbe interactions also limit the progress in this field [33]. There was a significant positive effect acknowledged by our results. Grass silages made with the addition of an inoculant containing the starter culture of L. buchneri KKP 2047p and L. diolivorans KKP 2057p (Biogas A) or P. acidilactici KKP 2065p (Biogas B) were characterized by the content 
of 1,2-propanediol, 1-propanol and propionic acid at a level ensuring the extension of their aerobic stability from 4 to 7 days in comparison to untreated silages. It was found that the use of inoculants resulted in an approximately 10-30\% increase in biogas yield, including methane from this raw material. The combination of bacterial species used in the inoculant had a positive effect on the quality parameters of silages, in terms of their use in a biogas plant and therefore this direction of research is worth continuing. These results raise many questions regarding the biochemical background of interactions between the strains present in the bacterial starter culture. There is also a need to discuss whether other combinations of lactic acid bacteria strains could refine green biomass preservation for energy purposes. These issues should be further studied, and molecular biology tools should be used.

\section{Patents}

Patent PL no. 236769 “Nowy szczep bakterii Pediococcus acidilactici o zdolności metabilizowania 1,2-propanodiolu, zawierajacca go kultura starterowa oraz preparat." Zielińska K., Piasecka-Jóźwiak K., Świątek M., Miecznikowski A. (2018) [in Polish].

Supplementary Materials: The following are available online at https://www.mdpi.com/article/10 $.3390 /$ en14102843/s1, Table S1. Metabolite profile of supernatant resulting from co-fermentation of strains L. buchneri KKP 2047p and L. diolivorans KKP 2057p in medium containing 1,2-propanediol and glucose as a carbon sources; Table S2. Metabolite profile of supernatant resulting from P. acidilactici KKP 2065p culture and co-fermentation of strains L. buchneri KKP 2047p and P. acidilactici KKP 2065p in medium containing glucose and/or 1,2-propanediol as a carbon source.

Author Contributions: Conceptualization, K.Z. and A.F.; methodology, K.Z., K.P.-J. and R.C.; formal analysis, A.F. and R.C.; investigation, A.F., K.P.-J. and R.C.; resources, K.Z. and K.P.-J.; data curation, K.Z. and A.F.; writing—original draft preparation, K.Z. and A.F.; writing—review and editing, A.F., K.P.-J. and R.C.; visualization, A.F.; supervision, A.F.; project administration, K.Z. and K.P.-J.; funding acquisition, K.P.-J. All authors have read and agreed to the published version of the manuscript.

Funding: This research received no external funding.

Institutional Review Board Statement: Not applicable.

Informed Consent Statement: Not applicable.

Conflicts of Interest: The authors declare no conflict of interest.

\section{References}

1. Sun, Z.; Yu, J.; Dan, T.; Zhang, W.; Zhang, H. Phylogenesis and Evolution of Lactic Acid Bacteria. In Lactic Acid Bacteria; Metzler, J.B., Ed.; CRC Press: Boca Raton, FL, USA, 2014; pp. 1-101.

2. Nishino, N.; Yoshida, M.; Shiota, H.; Sakaguchi, E. Accumulation of 1,2-propanediol and enhancement of aerobic stability in whole crop maize silage inoculated with Lactobacillus buchneri. J. Appl. Microbiol. 2003, 94, 800-807. [CrossRef]

3. Jatkauskas, J.; Vrotniakiene, V.; Ohlsson, C.; Lund, B. The effects of three silage inoculants on aerobic stability in grass, clover-grass, lucerne and maize silages. Agric. Food Sci. 2013, 22, 137-144. [CrossRef]

4. Soucaille, P.; Meynial-Salles, I.; Voelker, F.; Figge, R. Microorganisms and Methods for Production of 1,2-Propanediol and Acetol. U.S. Patent Application 9051588, 9 June 2015.

5. Awe, O.W.; Zhao, Y.; Nzihou, A.; Minh, D.P.; Lyczko, N. A Review of Biogas Utilisation, Purification and Upgrading Technologies. Waste Biomass Valorization 2017, 8, 267-283. [CrossRef]

6. Herrmann, C.; Idler, C.; Heiermann, M. Improving aerobic stability and biogas production of maize silage using silage additives. Bioresour. Technol. 2015, 197, 393-403. [CrossRef] [PubMed]

7. Amon, T.; Amon, B.; Kryvoruchko, V.; Zollitsch, W.; Mayer, K.; Gruber, L. Biogas production from maize and dairy cattle manure-Influence of biomass composition on the methane yield. Agric. Ecosyst. Environ. 2007, 118, 173-182. [CrossRef]

8. McEniry, J.; Allen, E.; Murphy, J.; O'Kiely, P. Grass for biogas production: The impact of silage fermentation characteristics on methane yield in two contrasting biomethane potential test systems. Renew. Energy 2014, 63, 524-530. [CrossRef]

9. Muck, R.; Nadeau, E.; McAllister, T.; Contreras-Govea, F.; Santos, M.; Kung, L. Silage review: Recent advances and future uses of silage additives. J. Dairy Sci. 2018, 101, 3980-4000. [CrossRef]

10. Kung, L.; Taylor, C.; Lynch, M.; Neylon, J. The Effect of Treating Alfalfa with Lactobacillus buchneri 40788 on Silage Fermentation, Aerobic Stability, and Nutritive Value for Lactating Dairy Cows. J. Dairy Sci. 2003, 86, 336-343. [CrossRef]

11. Elferink, S.J.W.H.O.; Krooneman, J.; Gottschal, J.C.; Spoelstra, S.F.; Faber, F.; Driehuis, F. Anaerobic Conversion of Lactic Acid to Acetic Acid and 1,2-Propanediol by Lactobacillus buchneri. Appl. Environ. Microbiol. 2001, 67, 125-132. [CrossRef] 
12. Krooneman, J.; Faber, F.; Alderkamp, A.C.; Elferink, S.J.H.W.O.; Driehuis, F.; Cleenwerck, I.; Swings, J.; Gottschal, J.C.; Vancanneyt, M. Lactobacillus diolivorans sp. nov., a 1,2-propanediol-degrading bacterium isolated from aerobically stable maize silage. Int. J. Syst. Evol. Microbiol. 2002, 52, 639-646. [CrossRef]

13. Toraya, T. The structure and the mechanism of action of coenzyme B12-dependent diol dehydratases. J. Mol. Catal. B Enzym. 2000, 10, 87-106. [CrossRef]

14. Taranto, M.P.; Vera, J.L.; Hugenholtz, J.; De Valdez, G.F.; Sesma, F. Lactobacillus reuteri CRL1098 Produces Cobalamin. J. Bacteriol. 2003, 185, 5643-5647. [CrossRef]

15. Sriramulu, D.D.; Liang, M.; Hernandez-Romero, D.; Raux-Deery, E.; Lünsdorf, H.; Parsons, J.B.; Warren, M.J.; Prentice, M.B. Lactobacillus reuteri DSM 20016 Produces Cobalamin-Dependent Diol Dehydratase in Metabolosomes and Metabolizes 1,2Propanediol by Disproportionation. J. Bacteriol. 2008, 190, 4559-4567. [CrossRef]

16. Zielińska, K.; Fabiszewska, A.; Świątek, M.; Szymanowska-Powałowska, D. Evaluation of the ability to metabolize 1,2-propanediol by heterofermentative bacteria of the genus Lactobacillus. Electron. J. Biotechnol. 2017, 26, 60-63. [CrossRef]

17. Zielińska, K.J.; Fabiszewska, A.U. Improvement of the quality of maize grain silage by a synergistic action of selected lactobacilli strains. World J. Microbiol. Biotechnol. 2018, 34, 9. [CrossRef] [PubMed]

18. Andrighetto, C.; Zampese, L.; Lombardi, A. RAPD-PCR characterization of lactobacilli isolated from artisanal meat plants and traditional fermented sausages of Veneto region (Italy). Lett. Appl. Microbiol. 2001, 33, 26-30. [CrossRef] [PubMed]

19. Williams, J.G.; Kubelik, A.R.; Livak, K.J.; Rafalski, J.A.; Tingey, S.V. DNA polymorphisms amplified by arbitrary primers are useful as genetic markers. Nucleic Acids Res. 1990, 18, 6531-6535. [CrossRef] [PubMed]

20. Oneca, M.; Irigoyen, A.; Ortigosa, M.; Torre, P. PCR and RAPD identification ofL. plantarumstrains isolated from ovine milk and cheese. Geographical distribution of strains. FEMS Microbiol. Lett. 2003, 227, 271-277. [CrossRef]

21. Zielinska, K.; Fabiszewska, A.; Stefanska, I. Different aspects of Lactobacillus inoculants on the improvement of quality and safety of alfalfa silage. Chil. J. Agric. Res. 2015, 75, 298-306. [CrossRef]

22. German National Standard. German Standard Methods for the Examination of Water, Waste Water and Sludge; Sludge and Sediments (Group S); Determi-Nation of the Amenability to Anaerobic Digestion (S 8); DIN 38414-8; Deutsches Institut Fur Normung E.V.: Berlinm Germany, 1985.

23. Honig, H. Determination of Aerobic Deterioration; System Volkenrode-Institut fur Grunland und Futterpflanzenforschung der Bundesforsungszns talt fur Landwirtschaft Braunschweig-Volkenrode (FAL): Berlin, Germany, 1985.

24. Nelson, W. Applied Life Data Analysis; Wiley: Hoboken, NJ, USA, 1982.

25. Danner, H.; Holzer, M.; Mayrhuber, E.; Braun, R. Acetic Acid Increases Stability of Silage under Aerobic Conditions. Appl. Environ. Microbiol. 2003, 69, 562-567. [CrossRef]

26. Zhang, T.; Li, L.; Wang, X.-F.; Zeng, Z.-H.; Hu, Y.-G.; Cui, Z.-J. Effects of Lactobacillus buchneri and Lactobacillus plantarum on fermentation, aerobic stability, bacteria diversity and ruminal degradability of alfalfa silage. World J. Microbiol. Biotechnol. 2009, 25, 965-971. [CrossRef]

27. Lindsey, J.R.; Kung, L. Effects of combining Lactobacillus buchneri 40788 with various lactic acid bacteria on the fermentation and aerobic stability of corn silage. Anim. Feed Sci. Tech. 2010, 159, 105-109. [CrossRef]

28. Zhang, C.; Brandt, M.J.; Schwab, C.; Gänzle, M.G. Propionic acid production by cofermentation of Lactobacillus buchneri and Lactobacillus diolivorans in sourdough. Food Microbiol. 2010, 27, 390-395. [CrossRef]

29. Selwet, M. Influence of inoculation with Lactobacillus on fermentation, production of 1,2-propanediol and 1-propanol as well as Maize silage aerobic stability. Open Life Sci. 2020, 15, 373-378. [CrossRef] [PubMed]

30. Ellis, J.; Bannink, A.; Hindrichsen, I.; Kinley, R.; Pellikaan, W.; Milora, N.; Dijkstra, J. The effect of lactic acid bacteria included as a probiotic or silage inoculant on in vitro rumen digestibility, total gas and methane production. Anim. Feed. Sci. Technol. 2016, 211, 61-74. [CrossRef]

31. Khota, W.; Pholsen, S.; Higgs, D.; Cai, Y. Fermentation quality and in vitro methane production of sorghum silage prepared with cellulase and lactic acid bacteria. Asian Australas. J. Anim. Sci. 2017, 30, 1568-1574. [CrossRef] [PubMed]

32. Szlachta, J.; Prask, H.; Fugol, M.; Luberański, A. Effect of Mechanical Pre-Treatment of the Agricultural Substrates on Yield of Biogas and Kinetics of Anaerobic Digestion. Sustainability 2018, 10, 3669. [CrossRef]

33. Saad, M.M.; Eida, A.A.; Hirt, H. Tailoring plant-associated microbial inoculants in agriculture: A roadmap for successful application. J. Exp. Bot. 2020, 71, 3878-3901. [CrossRef] [PubMed] 